\title{
Developing Rights? Relating Discourse to Context and Practice
}

\author{
Jethro Pettit and Joanna Wheeler
}

There is not one rights agenda. Every concrete reality determines a different agenda. (A Mexican human rights activist)

\section{Introduction}

Enthusiasm for "rights-based approaches" to development has grown during the past decade, taking on diverse meanings within the policies and actions of development agencies, governments and civil society organisations. This "rise of rights" (Eyben 2003) has sparked much useful critical reflection about the origins of rights discourses, and what they mean in policy and practice. One of the key concerns, as with all development fashions, is 'what is really different this time?' Can this emerging focus on rights within the development arena help to bring about real changes in favour of poor and marginalised people? How do we know that "rights-based development" is not just putting new labels on old wine? Given the experience with other development trends, such as the widespread and often contradictory uses of "participation", this is a valid concern (Brock and Cornwall 2004). Why have rights been elevated within the development sector at this time and what does a rights-based approach mean in practice to different actors? How do the generalised directives of aid agencies relate to context-specific struggles for rights, rooted historically in experiences of exclusion and marginalisation? Will formal rights policies, and particularly those pursued within a development framework, strengthen existing efforts to realise rights and inclusion, or is there reason for caution?

These questions suggest that there are both dangers and opportunities in this convergence of rights and development and point to the need for deeper analysis and empirical evidence that might help to reduce the risks and build upon the synergies. This issue of the IDS Bulletin responds to this need. It draws together recent insights and research findings from a variety of sources. ${ }^{1}$ While it would be impossible to cover all of the issues and debates here, we include diverse perspectives and inquire across a spectrum of current thinking, policy and practice. Comparative and historical analyses of different donor policy discourses on rights (Part I) are contrasted with actual examples of policy processes to implement rights (Part II) and with case studies of bottom-up struggles to achieve rights in diverse contexts (Part III). This juxtaposition of donor discourses on rights with efforts to implement rights through policy and with experiences of social mobilisation around rights, provides a useful space in which to examine the key questions that arise about the pursuit of rights within a development framework (and of doing development through rights).

First, why the rights-based approach and why now? As Cornwall and Nyamu-Musembi argue in this issue, there are important historical and geopolitical forces behind the timing and framing of the rights-based discourse, which bear careful examination. Second, whose rights count? Between formal legal formulations of rights and the actual experiences of making rights substantive, questions of whose rights are being defined and claimed, by whom, and how, all become crucial. The articles in this issue emphasise the central importance of history and context in understanding how rights work in practice. Third, the process of making rights real is a political one, rather than a technical or procedural one, because it entails confronting the structural inequalities that underlie the negation of rights. Understanding how rights can shift power relations is essential to realising the potential of rights to contribute to change. Finally, a rights 
perspective, when understood within particular contexts and linked to strategies to shift power relations, has the potential to confront some of the most prominent assumptions of development orthodoxy and emerging agendas of security.

\section{Why rights-based development?}

It is useful to remember that the rights-based approach to development cannot be dismissed as simply a donor-driven agenda. Like all discourses, it combines an observed reality with a normative prescription. Doubts may be aroused by the way in which reality is perceived and re-articulated by powerful actors and by the intentions that may lie behind their prescriptions. But there are nonetheless, real trends that are grounded in history and experience and that may be open to diverse meanings and future directions. It is clear for example that in many contexts, the meaning of "rights" work has evolved in recent decades from an historical focus on human rights violations and concern for the legal protection of civil and political rights (Lauren 2004). In the post-Cold War and post-dictatorial climate, rights efforts have begun to embrace much broader concerns (earlier suppressed as a socialist block agenda) for human dignity, access to resources and social and economic inclusion, usually captured by the shorthand "economic, social and cultural" (ESC) rights (Cornwall and Nyamu-Musembi, this issue). With this shift, many rights proponents recognised the need to engage with development actors and their strategies and with increasingly organised civil societies and social movements (Mwasaru, this issue). The human rights field, largely dominated by legal experts, needed additional skills such as community organising, capacity-building and participatory appraisal, as well as sectoral knowledge in areas such as health, education and natural resources. A different mix of institutions was also required, with a stronger role for non-governmental organisations (NGOs), community-based organisations and membership associations in articulating the "demand side" rather than relying so heavily on professionals to advocate on their behalf (Gaventa and Edwards 2001). In short, rights needed development and to engage more directly with civil society causes.

At the same time, development practitioners have begun to recognise the limits of their technical and micro-project approaches in tackling the root causes of poverty. They have realised the need to address deeper structures of inequality and exclusion and to confront these at the legal and political as well as social, cultural and economic levels. The disillusionment with projects can be seen in efforts by official agencies to scale up participatory methods into processes of policy making, service delivery and governance, as well as in the move by NGOs (national and international), to engage in advocacy and mobilisation. Missing from much of this "mainstreaming", however, was the dimension of rights and obligations: the legal, political and social processes needed to ensure that basic development commitments are met. This includes legal reforms and enforcement in addition to public awareness and action as methods of voicing demand and seeking accountability. The rise of more vocal and organised civil societies and social movements in many contexts also blurred the traditional lines between rights and development. Development therefore needed rights as much as rights needed development. This is evident, for example, in the proposal that rights must play a central role in achieving the Millennium Development Goals (Shetty, this issue).

These real and observable trends gave rise, perhaps inevitably, to the donor-articulated concept of rights-based approaches, albeit with particular desired outcomes and instrumentalities. As noted by Cornwall and Nyamu-Musembi, and Piron, for example, rights-based approaches responded to donors' needs for new mechanisms of government accountability in an aid climate of sector and budget support. Further, unlike the "right to development" debates of the 1970s and 1980s, the rights-based approaches discourse has largely been articulated in ways that sidestep questions of Northern, donor country or multinational corporate duties and obligations with respect to the rights of poor people in the South: the emphasis is entirely on the citizenstate relationship at country level. And there are many valid concerns that rights are being technically packaged in ways that ignore power and structural inequalities (e.g. Miller et al., page 31 this issue), and that valuable lessons are being ignored from the 'lost innovations' of earlier rights and empowerment strategies (Miller et al., page 52 this issue). At the same time, discourses can provide openings for legitimising bottom-up rights aspirations. There are many cases in which 
international rights discourses and covenants have been used effectively to leverage and enforce national-level change. There are signs that the rightsbased approaches language could be of similar strategic value for rights advocates in certain contexts, as well as carrying risks of cooptation. Much will depend on how rights-based approaches are understood and challenged, in context.

\section{Whose rights?}

The question 'whose rights?' is not just about who is able to claim certain rights, but also raises the importance of recognising the political and social history that had led to both legal and informal formulations of rights. And within this landscape, the appropriation of rights by development discourse is understood in relation to this genealogy of the origins of rights. This process of defining rights through international conventions and laws has been long and politically fraught (NyamuMusembi and Cornwall 2004). Similarly, the recent national constitution of countries like Brazil and South Africa have been held up as examples of progressiveness and broadly defined rights. But as Miller et al. (page 52) and Pereira Júnior et al. argue in this issue, the forces that have advocated for rights are many and draw on the depth of decades of social mobilisation around popular education, civil rights, women's rights, labour rights, etc. If the international and national legal frameworks for rights have been, at least in part, the fruit of many years of mobilisation and pressure, then movements for social justice themselves have both framed and defined rights in their own contexts and also employed international and national law strategically to support their efforts.

While some rights are defined by international and national legal frameworks, other formulations of rights are being advanced by donors as part of the increasing focus on the rights-based agenda (see Piron, this issue). But rights are also given meaning through struggles around access to resources, demands for recognition, and social justice. This issue provides several examples of actual struggles for rights within particular contexts. Musyoki and Nyamu-Musembi describe the efforts by tenants' associations in Mombasa, Kenya to define and claim rights to housing. Their efforts draw on international and national legal definitions of rights, but also expand these definitions in the context of the council housing estates where they live. Pereira Junior et al. relate the history of the right to participation from the perspective of civil society organisations in Brazil. In opposition to powerful elites and later the military government, Brazilian NGOs have articulated a strong sense of the relationship between participation, power and rights; and the importance of these to promoting substantive citizenship and social justice in Brazil. Williams shows how children's organisations in India are articulating their right to participation by creating spaces for interaction with policy makers. Clark et al.'s reflections on gender and rights draw on examples from women's movements, which have been at the forefront of redefining rights in practice and in international law for some time. Mwasaru compares popular efforts to secure ESC rights in Kenya, Haiti and the Philippines. He finds the lack of provisions for legal enforcement of ESC rights in international frameworks leads to diverse social initiatives to define, demand and make these rights "justiciable", often in unique ways.

What emerges from these examples is that the perspective of marginalised groups alters how formal rights are given meaning. Rights, in practice, are defined in part by legal frameworks and donor discourse, but these are also challenged and appropriated through social mobilisation that promotes actor-orientated rights. One of the key differences between donor discourses on rights and bottom-up understandings of rights is that development actors are generally motivated by what is the perceived need for development, to which rights are framed as a solution. By contrast, social mobilisations around rights do not necessarily take the need for development as their starting point. Many of the cases mentioned here are concerned with broad goals of social justice, access to economic resources, political change and empowerment.

This is not to argue that social movements are somehow necessarily virtuous and democratic, they can also act to reinforce power relations and exclusions. As Navarro argues in this issue, even while social struggles like the landless movement in Brazil are advancing certain rights, a lack of transparency and legitimate representations in terms of their own internal organisation can lead to the negation of other rights for the marginalised groups they are meant to help. In fact, community-based organisation raises serious questions about how different voices and interests are aggregated and represented (see Guijt and Shah 1998). But the role 
of civil society is crucial in making rights more substantive because civil society can help articulate connections between what makes rights become substantive in terms of people's actual experiences and formal rights frameworks, where they exist and vitally, to contribute to their framing where they do not exist. But attention to these cases of mobilisation for rights does throw into relief the importance of political, economic and social context, in informing how rights are defined and used in practice.

Some of the articles in this IDS Bulletin are drawn from a recent collaborative study exploring the gaps and linkages between rights and participation in practice. ${ }^{2}$ Seven country research teams, all deeply knowledgeable about their national contexts, mapped the influence of historical trends and present-day social and political conditions on the ways in which rights and participation have been understood, approached, linked and separated over time, as well as looking at the influences of international rights and development thinking and protocols. A recurrent theme running through nearly all of the country studies is the historical schism between civil and political rights work on the one hand and campaigns for economic, social and cultural rights on the other; a separation that has begun to dissolve over time. Concern for the protection of civil and political rights emerged in nearly all cases in response to periods of repressive or military rule involving violations of human rights. However, the character of these efforts varied according to historical and legal context. In both India and Mexico during the 1960s and 1970s, for example, growing popular frustration with elite control of political power and development resources was met at times with violent repression. This gave rise to human rights campaigns based on formal legal strategies (Jasis and Garcia 2004; NCA 2004). In both countries, subsequent human rights efforts and understandings were very strongly defined by these violations and responses. Yet over time there has been a bridging of common ground with social movements which have advocated for the social and economic rights of excluded sectors.

In both Zimbabwe and Nigeria, understandings of human rights were similarly defined by the efforts of political opposition groups to voice their demands and defend their freedoms within the context of formal legal systems defined by the colonial legacy and not embedded in the realities of national cultures, power relations and traditional or customary laws (Makanje et al. 2004; Toyo et al. 2004). Human rights work in both contexts was for a long time limited to formal legal education and defence campaigns and focused on those civil and political rights that could be upheld under the limited provisions of their constitutions. These rights groups developed significant experience in advocacy and in the use of international frameworks to demand rights not protected at the national level (Toyo et al. 2004). But the scope of their efforts proved too limited in the context of emerging struggles for more equitable access to resources. The distinction between political and civil rights on the one hand and economic, social and cultural rights on the other, became less important as the broader claims of social movements emerged. In Zimbabwe, the women's movement played a vital role in demonstrating the indivisibility of rights and bridging these communities (Makanje et al. 2004).

Rights in the Niger Delta, articulated around issues of self-determination and control of natural resources, also challenged the limited scope of the formal rights tradition in Nigeria; while in the North West region, the Muslim women's movement has framed rights not through the constitution or international law, but through broader social advocacy of alternative views about the role and status of women within religious law (Toyo et al. 2004). In contrast to women's rights campaigns in other countries, claiming universal rights was seen as a risky cause that Muslim women felt needed to be fought within their cultural and religious context, seeking to reclaim their rights within Shari'a (ibid).

What emerges from these country studies and from the case studies reported in this issue from Kenya (Musyoki and Nyamu-Musembi), Brazil (Pereira Júnior et al.) and from the comparative reflections on Kenya, Haiti and the Philippines (Mwasaru), is a strong picture of the diverse, historically rooted and context-sensitive nature of rights struggles. In Kenya a formal, legally oriented human rights tradition, again shaped by civil and political opposition campaigns and by the limitations of a post-colonial constitution, is seeking to some extent to redefine itself by "rooting rights" in the expressed social and economic needs of marginalised and excluded sectors, while at the same time social movements are emerging and articulating demands without necessarily making 
use of formal rights language or legal procedures (Musyoki and Nyamu-Musembi; Mwasaru). In Brazil, social movements and allied NGOs have for many decades combined social and economic rights struggles with advocacy for civil and political reform, in an historical context in which "development" has not been treated as a separate, neutral exercise from realising democracy, rights and citizenship; yet there is a concern that rights-based approaches may be an effort by some conservative forces to dilute this indivisible and political meaning of rights within the Brazilian context (Pereira Júnior et al. 2004).

These diverse experiences in defining and claiming rights invite some optimism about the potential for self-determined strategies for achieving rights, even where the wider discourses have also been influential, or have been perceived as too interventionist, as prescriptive or culturally insensitive, or as lacking "teeth". Rights are being pursued in multiple ways, often deeply rooted in local context, history and conditions, as well as through engagement with and support from more international discourses. What these studies also reveal is the intensely political nature of rights struggles in situations of high levels of poverty and inequality and of the importance of analysing and confronting deeply embedded power relations and structural barriers on the road to securing rights. It is in this sense that framing rights within development, which had often been treated as a politically neutral process, is problematic. We turn to this challenge next.

\section{Making rights real}

Another major question arising is that of how rights become substantive or actualised in practice and what are the structural and power implications of this process? The negation of rights, whether political, economic, social or cultural, is nearly always predicated on structural and relational factors that lead to exclusion, marginalisation and injustice. This is an important starting point for examining struggles for rights and the barriers to substantiating them. The negation of rights can be very powerful, especially as it often involves a constellation of forces arrayed against the potential fulfilment of that right. Institutionalised forms of racial and gender discrimination and the long and difficult path to securing the rights of women and ethnic or racial minorities (or in some cases majorities) in nearly all societies, are obvious examples. The implications of understanding rights in development from the perspective of the negation of rights, requires examining how the fulfilment of rights must confront the underlying interests behind the causes of exclusion. While there are specific objects of rights struggles (e.g. legalised land rights in the case of Kenya, or protection against domestic violence in the case of women's movements), the process of achieving these substantive and specific goals in practice involves a process of confronting the embedded power relations that have perpetuated the negation of these rights in the first place.

One challenge in doing this is the limited capacity for analysis and shifting of power in the development aid sector, which has become highly specialised and professional in sectoral areas but often lacks basic political and social understanding. Miller et al. (page 31 this issue) provide a useful review of some practical and theoretical frameworks for analysing and addressing power. In particular, these tools point to the limitations of Western "pluralist" assumptions about the ways in which conflicting interests are negotiated and decisions made; there are often culturally and ideologically embedded forms of power which shape social values, norms and behaviours and determine what issues are even considered legitimate for debate (ibid). This "invisible power" also has a direct bearing on the sense of dignity and self-worth of excluded people, or their "power within", and will affect their capacity to speak and advocate for their rights. Strategies which address the legal or procedural barriers to rights, and even those which seek to deliver rights as material services, will usually fail unless work is done to shift "invisible power" and to strengthen "power within". This has been the core intention of many social movements throughout history, not necessarily to seize power but to change the accepted norms which validate and perpetuate both the structure and agency of power relations.

It is in this sense that there is so much to learn and recover from proven rights strategies which have involved the building of awareness and selfconfidence, the use of popular education and communication, methods for reflective action, leadership development, and the forging of common visions, understandings and alliances; often well before any direct attempts at legal or political action (Miller et al., page 52 this issue). Yet there are valid 
concerns that many of the innovative methods and lessons that can found, historically, in these approaches to social and political transformation are noticeably absent from current articulations of rights-based approaches to development. There is a sense therefore of lost opportunity and a warning that taking formal, visible and procedural steps toward making rights real within a development programme framework may easily miss the underlying foundational processes involved in building social awareness and lasting change.

\section{Can rights challenge development orthodoxy?}

Despite the earlier cautions we have raised about de-linking rights from context and the risks of separating rights policy from power analysis, the potential of rights-based approaches to challenge development orthodoxy remains. Given the strong trends towards the marketisation and the scaling back of state services promoted by the World Bank, the International Monetary Fund (IMF) and many national governments; and the wholesale exportation of hegemonic models of democracy by the United States Agency for International Development (USAID) and others as part of the wider "good governance" agenda, what can this discussion of rights offer?

First, bringing rights into development challenges some of the fundamental assumptions implicit within neoliberal reforms about the nature of state/society relations. Using rights in development requires attention to both sides of the equation, from claims for rights by citizens to the obligation and duties of the state to uphold those rights. As Cornwall and Nyamu-Musembi, and Piron argue in this issue, the obligation/duty side of the coin is part of the reason that the right-todevelopment has not been promoted more widely and why commitment to rights by donor agencies have been only rhetorical in certain cases. But as many of the articles in this issue argue, ensuring substantive rights involves both institutions which are able to respond to rights claims and citizens and social organisations that engage with these institutions to shape the meaning of rights and how they are promoted in practice. When these two sides of the equation can come together the potential for change that benefits poor and marginalised groups is more likely to be realised (see Blackburn et al. this issue).
Second, many of the contributions to this IDS Bulletin point out that making rights substantive in practice involves understanding how context, political processes and relationships of power inform rights. Like "participation" and "good governance" agendas in development before, a technical and abstracted approach inevitably leads to the perversion of the potential of these approaches to lead to positive change. As Part II of this issue highlights, policies seeking to promote rights in development are consistently confronted by the complexities of political realities. The political aspects and power relationships that pervade development are often edited out of development discourse (Eyben 2004). For example, the trend of promoting "empowerment" focuses in most cases on changing the abilities of particular individuals to be more able to control their lives. One of the critiques of the use of empowerment in development programmes is that it tends to focus on the powers of individuals to do something differently, but fails to address the structural causes of marginalisation and the power relations that perpetuate those. The assumption is that one sector of society can be empowered without necessarily challenging the power of other sectors, or questioning the norms and values that uphold that power.

Using rights in development requires understanding the potential of rights to challenge these political realities and also the obligations and responsibilities necessary to support shifts in the structural causes of marginalisation. As Hughes et al. describe, using rights in practice is very challenging and filled with contradictions and tensions. While economic, social and political rights are indivisible in practice, this does not imply that there will be no conflicts between rights. Rightsbased approaches, if reduced to technical and operational plans that ignore political context and power relations, will fail to be effective in promoting social justice in a sustainable way.

\section{Conclusion}

Are rights-based approaches to development adrift from any coherent normative framework (as Piron argues in this issue), or from social and political contexts (as several of the case studies point out)? If so, what are the implications for the impact that using rights can have? Rights are alternately treated as a technical fix or rejected by development agencies for seeming to lack the ability to generate 
pro-poor growth. But despite this, the growing attention on rights is raising another possibility that rights will be used selectively by powerful development actors to foster a favourable environment for marketisation, or to justify a growing focus on security and and anti-terrorism concerns. In the same way that democracy was used by the West during the Cold War as a battering ram to open markets, shore up military and autocratic governments, and legitimise invasions to check Soviet power, the ostensible international concensus around rights risks being used to further the interests of the powerful, rather than being a path for challenging marginalisation and exclusion.

There are justifiable fears that the rights-based approach is a donor-driven agenda with a deeper purpose of reinforcing neo-liberal values and interests, or of imposing singular Western notions of what rights and development mean (Escobar 1994). Many of the articles in this IDS Bulletin raise important concerns about the motives driving rights-based approach language and policy and about the denial of valuable historical innovations and traditions related to securing rights in both the North and the South. But because discourse both describes observed realties and prescribes desired outcomes, there is always scope to re-examine the observed real events and trends that have given rise to rights, and the assumptions behind those observations and to discover different interpretations and forward projections of these same experiences. The struggle for rights is happening, with or without discourse and policy and it is not simply an agenda of the powerful. What emerges is a vibrant picture of often diverse meanings and strategies being pursued throughout the world, rooted in national

\section{Notes}

1. The major sources for this IDS Bulletin are derived from two collaborative research projects. The first, 'Linking rights and participation', involved the Participation Group at IDS, Just Associates (Washington) and seven country partners and was jointly supported by the UK Department for International Development (DFID), the Swedish International Development Agency (Sida) and the Swiss Agency for Development Cooperation (SDC). The second is the Development Research Centre on Citizenship, Participation and Accountability, a consortium of six regional partners coordinated by IDS and supported by DFID. Additional articles were generously submitted by colleagues from other research programmes and histories and contexts as well as connected with international rights language and global movements. Many realities and discourses become apparent, the lines between them often blurred, each with past trajectories and alternative pathways into the future. If the current enthusiasm for rights in development can open up space for thinking and action appropriate to the particularities of each moment and context, rather than serving as a onesize-fits-all export, then rights-based approaches are to be welcomed.

This location of rights within specific realities is not to venture onto the thin ice of debates about cultural relativism or particular vs universal rights (Walzer 1994; Taylor 1998; Walker 1988), but to move beyond these old debates and simply to recognise that for rights to become meaningful, they must be claimed and realised by real people engaged in specific struggles related to urgently felt needs (Nyamu-Musembi, this issue). And to be sustainable, the process for securing those rights needs to be one which squarely addresses the structural inequalities and power relations which deny them in the first place. Rights are both about physical needs and personal experiences of power and citizenship. Such processes are long fought and hard won, involving deep societal reflection and awareness that can alter the many-layered fabric of power, in addition to the visible frameworks, legal reforms, political actions and development initiatives needed to deliver rights in tangible ways. Rights and development discourses and policies are highly contested arenas with inherent agendas, biases, risks and potentials, yet with ample scope remaining to discover what rights will ultimately mean in context and practice.

institutions. The editors gratefully acknowledge the many individuals whose work, directly and indirectly, has contributed to this issue of the IDS Bulletin.

2. Two of the seven country studies (Kenya and Brazil) and one comparative study (Kenya, Haiti, Philippines) from the 'Linking rights and participation' study are reported in articles in this IDS Bulletin (in addition to the discourse reviews in Part I). The analysis in this introduction draws on these and the remaining country studies (India, Indonesia, Nigeria, Mexico and Zimbabwe), which are referenced at the end of this article and may be accessed online: www.ids.ac.uk/ids/particip/research/rights 


\section{References}

Brock, K. and Cornwall, A., 2004, 'Beyond buzzwords: "poverty reduction", "participation" and "empowerment" in development policy', UNRISD Programme Paper, Geneva: United Nations Research Institute for Social Development.

Escobar, A., 1994, Encountering Development: The Making and Un-making of the Third World, Princeton: Princeton University Press

Eyben, R., 2003, 'The rise of rights: rights-based approaches to international development', IDS Policy Briefing 17, May, Brighton: Institute of Development Studies

Eyben, R., 2004, 'Linking power and participation', Background Paper for World Bank/DFID Workshop on Power, Washington, D.C., 23-24 March (unpublished)

Jasis, M. and Garcia, M., 2004, 'Linking rights and participation: Mexico country study - exploring the relationship between human rights and citizen participation', Brighton: Institute of Development Studies, www.ids.ac.uk/ids/particip/research/rights (accessed December 2004)

Gaventa, J. and Edwards, M., 2001, Global Citizen Action, Boulder, CO: Lynne Reiner Publishers

Guijt, I. and Shah, M.K., 1998, Myths of Community: Gender Issues in Participatory Development, London: Intermediate Technology Development Group Press

Lauren, P.G., 2004, The Evolution of International Human Rights: Visions Seen. Pittsburgh: University of Pennsylvania Press

Lumbantobing, D. and Zulminarni, N., 2004, 'Linking rights and participation: Indonesia country study', Brighton: Institute of Development Studies, www.ids.ac.uk/ids/particip/ research/rights (accessed December 2004)
Makanje, R., Shaba, L.M. and Win, E.J., 2004 , Linking Rights and Participation: Zimbabwe Country Study, Brighton: Institute of Development Studies, www.ids.ac.uk/ids/particip/research/ rights (accessed December 2004)

Musyoki, S., Nyamu-Musembi, C., Mwasaru, M. and Mtsami, P., 'Linking rights and participation: Kenya country study', Brighton: Institute of Development Studies

National Centre for Advocacy Studies, 2004, Linking Rights and Participation: India Country Study, Brighton: Institute of Development Studies, www.ids.ac.uk/ids/particip/research/rights (accessed December 2004)

Nyamu-Musembi, C. and Cornwall, A., 2004, "What is the "Rights-Based Approach" all about? Perspectives from International Development Agencies', IDS Working Paper 234, Brighton: Institute of Development Studies

Pereira Júnior, A.R., Antunes, M. and Romano, J., 2004, Linking Rights and Participation: Brazil Country Study, Rio de Janeiro: ActionAid Brasil, www.ids.ac.uk/ids/particip/research/rights/ (accessed December 2004)

Taylor, C., 1998, Multiculturalism, Princeton: Princeton University Press

Toyo, N., with Nweze, J.C.C., Agary, K., Agary, T.K., Abdu, H. and Nai'ya Sada, I., 2004, Linking Rights and Participation: Nigeria Country Study - Exploring Experiences from the Niger Delta and North West Regions, Brighton: Institute of Development Studies, www.ids.ac.uk/ids/particip/ research/ rights (accessed December 2004)

Walker, R.B.J., 1988, One World, Many Worlds: Struggles for a Just World Peace, Boulder, CO: Lynne Rienner

Walzer, M., 1994, Thick and Thin: Moral Argument at Home and Abroad, South Bend, Ind.: Notre Dame University Press 